\title{
Localization of $\alpha$-L-Arabinofuranosidase and Acid Phosphatase in Mycelium of Sclerotinia fructigena
}

\author{
By E. C. HISLOP, VIVIEN M. BARNABY, CLAIRE SHELLIS \\ AND F. LABORDA \\ Long Ashton Research Station, University of Bristol, \\ Bristol, BS 8 9AF
}

(Received 6 July 1973; revised 24 September 1973)

\begin{abstract}
SUMMARY
$\alpha$-L-Arabinofuranosidase (AF) and acid $p$-nitrophenyl phosphatase (AP) were secreted by Sclerotinia fructigena grown in a liquid pectin/ammonium tartrate medium. 'Gentle' mechanical manipulation of mycelium solubilized most of the AF and much of the AP, while brief acid treatment considerably inactivated both enzymes. Both enzymes were present predominantly in a soluble form in homogenates prepared for subcellular fractionation, but some particulate activity of both was recovered from a sucrose density gradient in a fraction which also contained mitochondria. Azo-dye techniques with appropriate I-naphthyl derivatives as substrates and $p$-(acetoxymercuric) aniline diazotate as capturing agent produced similar staining patterns for both enzymes in the light and electron microscopes, but the distribution of $\beta$-glycerophosphatase activity as visualized by the Gomori technique was more variable. A proportion of the activity of the enzymes remaining after fixation was located between the plasmalemma and the hyphal wall, in vacuoles in the cytoplasm, and in spherosome-like bodies. Some evidence was obtained for structure-linked latency of both enzymes and for their secretion by a process of reverse pinocytosis.
\end{abstract}

\section{INTRODUCTION}

The importance in pathogenesis of cytolytic enzymes secreted by Sclerotinia fructigena Ader. \& Ruhl (relevant literature cited in Archer, 1973) has been the subject of considerable study over many years. Although the macerating and killing effects of extracellular pectolytic enzymes have been the most studied of all the potential determinants of the pathogenicity of $S$. fructigena, the recent work of Howell (1972) drew particular attention to the possible importance of an $\alpha$-L-arabinofuranosidase (AF) which, of the enzymes studied by her in a large number of isolates, showed the strongest positive correlation with aggressiveness (as measured by the rate of linear advance) in vivo. This glycosidase was first identified in the culture medium in which $S$. fructigena had been grown by Byrde \& Fielding (1965) and was then thought to be involved in tissue maceration but was later shown (Byrde $\&$ Fielding, I968) to be devoid of such activity. Subsequent partial purification of AF (Fielding \& Byrde, 1969) showed that the extracellular enzyme existed in multiple forms and this was confirmed and extended by Laborda, Fielding \& Byrde (1973), who demonstrated that most of the extracellular activity was attributable to an isoenzyme with a pI value of 6.5 and the remainder of the activity to one with a pI value of $3 \cdot 0$. These isoenzymes were also detected in mycelial homogenates, but the bulk of the activity here occurred in a form with a pI value of $4 \cdot 5$. 
The arabinofuranosidase enzyme was detected in infected apples (Calonge, Fielding \& Byrde, 1969), and on the basis of ultrastructural observations it was suggested that multivesicular bodies may have a functional role in the secretion of this and pectolytic enzymes in vivo, although a similar study by Maxwell, Williams \& Maxwell (1972) with Sclerotinia sclerotiorum failed to establish such a relationship in that species. Early studies on the localization of AF in the mycelium of $S$. fructigena (E. C. Hislop, unpublished) by histochemical means using 2-naphthyl arabinofuranoside as substrate, prepared for this purpose by Fielding \& Hough (I97I), and with hexazonium pararosaniline as a coupling agent showed the enzyme to be localized at particulate sites, but the technique used then did not reveal the ultrastructural localization of the enzyme.

The potential importance of AF in pathogenesis and the desirability of a better understanding of its biosynthesis and secretion prompted the current work on its histochemical and cytochemical localization. For comparison, parallel studies were made with acid phosphatase which is also secreted by Sclerotinia fructigena and which can be examined by the same technique as used for AF and for which some data on the histochemical and cytochemical localization in fungi are available (e.g. Wilson, Stiers \& Smith, I970; Cartledge \& Lloyd, I $972 a, b$ ).

\section{METHODS}

Cultures. The isolate of Sclerotinia fructigena (ATCC26I06) used throughout was isolated from a naturally infected apple fruit and kept under oil on potato-carrot agar. Conidia produced on V-8 vegetable juice (Campbell's Soups Ltd, King's Lynn) agar were used to inoculate a liquid polypectate-ammonium tartrate medium (Byrde \& Fielding, 1968) with or without the addition of $0.06 \mathrm{M}$-glucose. Still and shake cultures were grown at $25^{\circ} \mathrm{C}$ for up to 7 days for enzyme production and secretion studies or for 3 to 4 days for cytochemical and histochemical work. Cultures were also grown on these media solidified with $2 \%(w / v)$ agar. Mycelium was usually separated from the culture medium by filtration, but for I- to 2-day-old cultures low-speed centrifugation was used $(600 \mathrm{~g})$. Where possible, mycelium to be fixed for histochemistry was removed from the culture with a hooked needle and placed in freshly prepared $4 \%(\mathrm{w} / \mathrm{v})$ paraformaldehyde in $0.1 \mathrm{M}$-sodium phosphate buffer, $\mathrm{pH} 7 \cdot 3$, at between 2 and $4{ }^{\circ} \mathrm{C}$ for up to $\mathrm{I} 8 \mathrm{~h}$. When solid cultures were to be fixed, the Petri dishes were flooded with cold fixative before small pieces of agar and mycelium $(\mathrm{I} \times 3 \times 2 \mathrm{~mm})$ were excised and placed in fresh fixative.

Disruption of mycelium. Material to be used for the production of subcellular organelles was broken by 'gentle' grinding with sand or with a glass tissue macerator and a minimal quantity of a cold medium containing $0.35 \mathrm{M}$-sucrose, $0.1 \%(\mathrm{w} / \mathrm{v})$ bovine serum albumin and I mM-EDTA in $0.05 \mathrm{M}$-tris- $\mathrm{HCl}$ buffer, $\mathrm{pH} \mathrm{7.2.} \mathrm{The} \mathrm{enzyme} \mathrm{complement} \mathrm{of} \mathrm{mycelium}$ was assayed in the supernatant fraction from homogenates produced by vigorously grinding mycelium with $0^{\cdot} \mathrm{I} \mathrm{M}$-acetate buffer, $\mathrm{pH} 5^{\circ} \mathrm{O}$, or with distilled water.

Subcellular fractionation. The turbid supernatant fraction from mycelial homogenates centrifuged at $3000 \mathrm{~g}$ for Io min at $4{ }^{\circ} \mathrm{C}$ was layered directly on to $\mathrm{I} 2 \mathrm{ml}$ of linear sucrose ( 0.6 to I. $8 \mathrm{M}$ ) or Ficoll (Pharmacia Ltd, Uppsala, Sweden; Io to $40 \%$, w/v) density gradients prepared in the grinding medium and centrifuged in an MSE 25 centrifuge at a maximum of $89000 \mathrm{~g}$ for $4 \mathrm{~h}$ at $4{ }^{\circ} \mathrm{C}$ before the tubes were punctured and I $\mathrm{ml}$ fractions collected.

Enzyme assays. Triton X-I00 $(0.04 \%$, w/v) was added to the assay mixtures and specific activities calculated after protein determination by the method of Lowry, Rosebrough, Farr \& Randall (195I).

AF was assayed at $\mathrm{pH} 5.0$ by the method of Byrde \& Fielding (I968) with $p$-nitrophenyl 
$\alpha$-L-arabinofuranoside (Fielding \& Hough, 1965) as substrate, or by a method based on that of Bradshaw \& Rutter (I972) with I- or 2-naphthyl $\alpha$-L-arabinofuranosides (2.5 mM) as substrates and Fast Blue BB (G. T. Gurr Ltd, Romford, Essex) as the coupling agent to produce a dye, the extinction of which when extracted into ethyl acetate was measured at $540 \mathrm{~nm}$.

Acid phosphatase (EC. 3.I.3.2) was assayed at $\mathrm{pH} 5.0$ with $p$-nitrophenyl phosphate (Sigma Chemical Co. Ltd, St Louis, Missouri, U.S.A.), I-naphthyl phosphate (Koch-Light Co. Ltd, Colnbrook, Buckinghamshire) (cf. Bradshaw \& Rutter, I972) or sodium $\beta$ glycerophosphate (Taab Laboratories, Reading) by the method of Berthet \& de Duve (I95I) with liberated phosphate determined by the method of Fiske \& Subba Row (I925).

Succinate $\rightarrow$ cytochrome $c$ reductase was measured at $\mathrm{pH} 7 \cdot 4$ by the method of Ulrich \& Mathre (1972).

Acid deoxyribonuclease (EC. 3. I.4.5) was assayed by the method of Kunitz (1950) with salmon sperm sodium deoxyribonucleic acid (Calbiochem Ltd, Los Angeles, California, U.S.A.).

Separation of AF isoenzymes. Preparative separation and purification of AF isoenzymes was accomplished by isoelectric focusing of mycelial homogenates (Laborda, Fielding \& Byrde, 1973). Qualitative partial separation was achieved by modified (Hislop \& Stahmann, I97I) polyacrylamide gel electrophoresis (Davis \& Ornstein, I959) followed by visualization with 2-naphthyl $\alpha$-L-arabinofuranoside and Fast Garnet GBC diazonium salt (G. T. Gurr Ltd).

Histochemistry. Acid phosphatase was visualized with an optical microscope in unfixed mycelium and in mycelium fixed for up to $\mathrm{I} 8 \mathrm{~h}$ in cold $4 \%(\mathrm{w} / \mathrm{v})$ paraformaldehyde in $\mathrm{O} \cdot \mathrm{I} \mathrm{M}$ sodium phosphate buffer ( $\mathrm{pH} 7 \cdot 2$ to $7 \cdot 4)$ by the lead nitrate method of Gomori (1952). This enzyme and AF were also stained for observation in the light microscope by the standard simultaneous coupling azo-dye technique (Grogg \& Pearse, 1952) using I-naphthyl phosphate (Koch-Light Laboratories Ltd.) or I-naphthyl $\alpha$-L-arabinofuranoside respectively as substrates and Fast Garnet GBC salt or hexazotized pararosaniline (Davis \& Ornstein, I959; Lehrer \& Ornstein, 1959) as coupling agents with and without the addition of $6 \%(\mathrm{w} / \mathrm{v})$ polyvinylpyrrolidone. The naphthol AS-BI phosphate (Sigma Ltd.) post-coupling method for acid phosphatase (Burstone, I962) was used also with Fast Blue BB and Fast Red salts (G. T. Gurr Ltd). I-Naphthyl- $\alpha$-L-arabinofuranoside, with m.p. I 40 to I $42{ }^{\circ} \mathrm{C},[\alpha]_{\mathrm{D}}^{20}-\mathrm{I}$ I $2^{\circ}$ (c. 0.5 in methanol), was kindly prepared by Mr A. H. Fielding as described by Fielding \& Hough (197I) for the 2-naphthyl glycoside and characterized from nuclear magnetic resonance data by Professor L. Hough, Queen Elizabeth College, London, W.8 (personal communication).

Localization of both enzymes at the levels of the optical and electron microscopes was examined by simultaneous coupling of I-naphthyl substrates with hexazotized pararosaniline (Lehrer \& Ornstein, 1959) at $\mathrm{pH}$ values between $5^{\circ} \mathrm{O}$ and 6.5 and at temperatures between 4 and $25{ }^{\circ} \mathrm{C}$, or by a modification of the $p$-(acetoxymercuric) aniline diazotate method of Smith \& Fishman (I969) in which simultaneous coupling was carried out at $\mathrm{pH} 5.0$ and 18 to $20^{\circ} \mathrm{C}$. [Pararosaniline and $p$-(acetoxymercuric) aniline EM grades were from Taab Laboratories.] Fixed mycelium (usually $\mathrm{I} 6 \mathrm{~h}$ at $4{ }^{\circ} \mathrm{C}$ ) was washed for $\mathrm{I} \mathrm{h}$ in $\mathrm{O} \cdot \mathrm{I} \mathrm{M}$ sodium acetate buffer ( $\left.\mathrm{pH} 5^{\circ} \mathrm{O}\right)$ and incubated in mixtures containing 3 mM-substrate and diazotized coupling agent at the concentration used by Smith \& Fishman (I969) adjusted to $\mathrm{pH} 5^{\circ} \mathrm{O}$ with sodium hydroxide and buffered with $0^{\circ} \mathrm{I}$ M-sodium acetate. Good localization was usually observed for both enzymes within incubation times of $60 \mathrm{~min}$ at $20^{\circ} \mathrm{C}$. $\beta$ Glycerophosphatase activity was examined in the electron microscope by the same procedure as used for light microscopy, except that the ammonium sulphide step was omitted. 
Control incubations were carried out in mixtures lacking substrates and, for AF, with mycelium in which the enzyme had been partially repressed by the addition of glucose. A further control treatment for AP comprised inhibition of this enzyme by $10^{-2} \mathrm{M}$-sodium fluoride in the incubation medium. Heat-treated mycelium ( $100{ }^{\circ} \mathrm{C}$ for $5 \mathrm{~min}$ ) and mycelium pretreated with I-naphthol $(0.5 \mathrm{~mm})$ and then post-coupled after a short wash in acetate buffer were also examined. Ultrastructural localization of both enzymes was also attempted in unfixed mycelium by incubation in medium containing substrate, acetoxymercuric aniline diazotate and $22 \%(\mathrm{w} / \mathrm{v})$ polyvinyl alcohol (grade B05/I40, Cytochemical Co. Ltd, Edgware, Middlesex; Altman, I97I).

Microscopy. Direct observation of mycelium was made with a Zeiss R.A. microscope with standard optics or with phase-contrast or interference-contrast optics. Mycelium stained with $0.01 \%(\mathrm{w} / \mathrm{v})$ Nile Blue was examined by fluorescence microscopy. Mycelium for ultrastructural studies was post-fixed in $\mathrm{I} \cdot 5$ to $2 \cdot 0 \%(\mathrm{w} / \mathrm{v})$ aqueous osmic acid, adjusted to $\mathrm{pH} 7 \cdot 2$ with dilute (M/I00) sodium hydroxide for $2 \mathrm{~h}$ at $30{ }^{\circ} \mathrm{C}$ or $\mathrm{I} 6 \mathrm{~h}$ at $4{ }^{\circ} \mathrm{C}$ with or without prior treatment with $0.9 \%(\mathrm{w} / \mathrm{v})$ thiocarbohydrazide (Smith \& Fishman, 1969). Mycelium was usually post-stained with $2 \%(\mathrm{w} / \mathrm{v})$ aqueous uranyl acetate for $30 \mathrm{~min}$ at $25{ }^{\circ} \mathrm{C}$ before dehydration with ethanol and embedding in Araldite as described by Smith \& Fishman (I969), in Spurr's medium-hardness resin mix (Spurr, 1969) or in Epon (Luft, I96I). Thin sections (grey-silver) cut with a diamond knife and an LKB ultratome were mounted on copper grids without support films before staining with aqueous (or, rarely, methanolic) $2 \%(\mathrm{w} / \mathrm{v})$ uranyl acetate and/or lead citrate (Reynolds, 1963). Sections were examined in an AEI 60I B electron microscope operating at $60 \mathrm{kV}$, and results recorded on Ilford $\mathrm{N} 506 \times 9 \mathrm{~cm}$ photographic plates.

Latency of enzyme activity of both enzymes was examined by the techniques of Gahan (I965) using treatments including $4 \%(\mathrm{w} / \mathrm{v})$ neutral paraformaldehyde, $0.1 \%(\mathrm{w} / \mathrm{v})$ Triton $\mathrm{X}-\mathrm{I} O 0$, and repeated freezing and thawing.

\section{RESULTS}

\section{Biochemical}

The pattern of AF and AP synthesis (Fig. I $a$ ) and secretion (Fig. I $b$ ) in still-liquid culture, as measured by the hydrolysis of $p$-nitrophenyl substrates, indicated some glucose repression of AF production and secretion, and showed that acid phosphatase was produced and secreted at similar rates in cultures grown with and without glucose. Mycelium for histochemical staining was usually taken from still cultures $80 \mathrm{~h}$ old when the amount of AF in the culture liquid and in the mycelium from the glucose-supplemented medium was approximately 10 \% of that in de-repressed mycelium. Shake cultures showed a similar pattern of enzyme production and secretion to still cultures, except that comparable levels of the two enzymes were reached at an earlier age in shake culture and that less AF was produced in the presence of glucose. Mycelium for histochemistry was usually removed from shake cultures when they were $72 \mathrm{~h}$ old.

During the course of studies on the production of the two enzymes in liquid culture unexpected variation was sometimes encountered, and this was traced to methods used for handling the mycelium (Table I). When mycelium was washed gently several times in O.I M-acetate buffer ( $\mathrm{pH}^{\circ}{ }^{\circ}$ ) for example by inversion (treatment $\mathrm{A}$ ), only a very small amount of either enzyme was removed from the mycelium into the wash liquid. However, if the mycelium was agitated vigorously for $15 \mathrm{~s}$ on a 'Whirlimixer' (Fisons Scientific Apparatus Ltd; treatment B), a considerable proportion of enzyme, particularly AF, could 

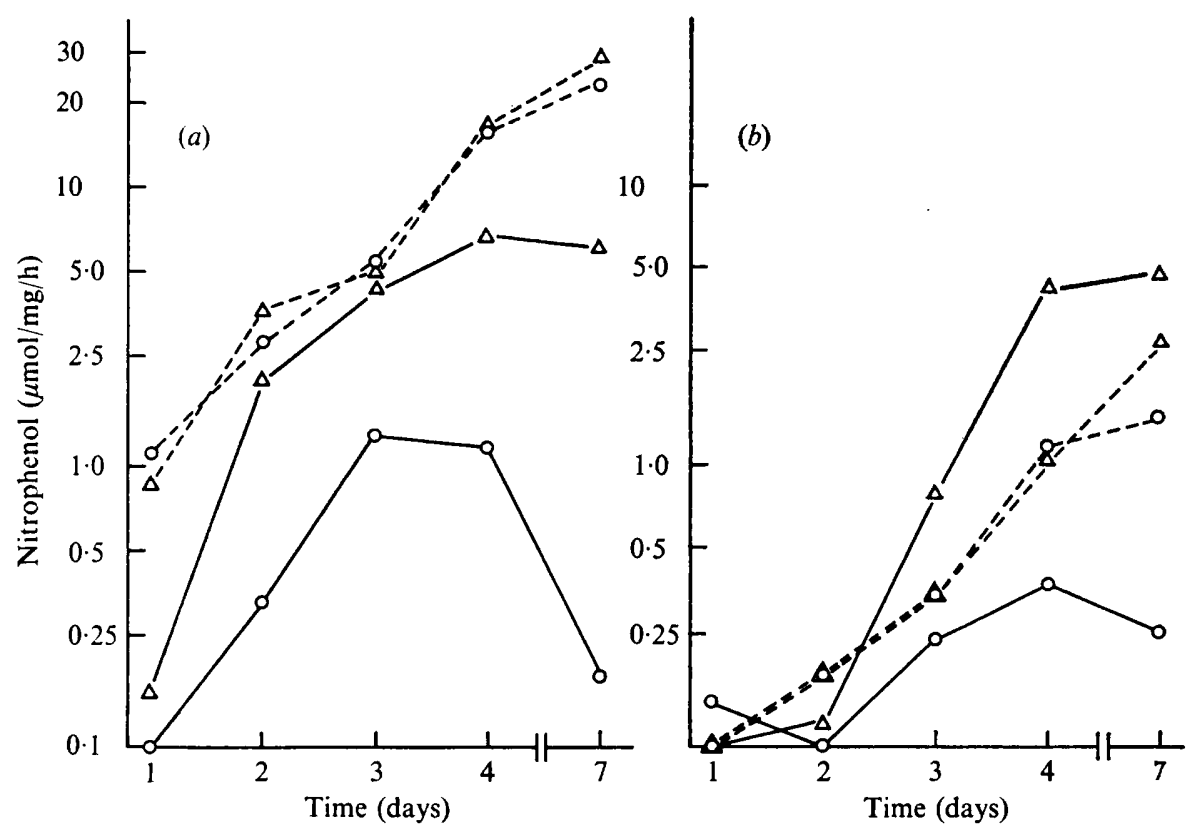

Fig. I. Specific activity of AF and AP in repressed ( $+G)$ and de-repressed ( $-G)$ mycelial homogenates $(a)$ and the corresponding culture filtrates $(b) .0-0, A F+G ; 0--O, A P+G$; $\triangle-\triangle, A F-G ; \triangle-\triangle, A P-G$.

be removed from the mycelium. More vigorous handling of the mycelium, such as sucking through a Pasteur pipette ten times (treatment $\mathbf{C}$ ) in a manner which might be used to break a mycelial pellet produced by centrifugation, often removed very large amounts of both enzymes from the mycelium grown in either still or shake culture. In an extreme case, $96 \%$ of the AF activity of mycelium grown in still culture was removed by sucking the hyphae through a pipette. This mycelium was not visibly damaged, as judged by observation with an optical microscope, but it could not be stained for AF activity by the usual histochemical techniques. In contrast to AF, which was apparently more easily removed from still-grown cultures, AP was removed more easily from shake cultures but the explanation for this is unknown. The total amounts of the two enzymes in the mycelium (Table I) are based on specific activities (to take account of the different weights of mycelium) in homogenates containing $0.04 \%$ Triton X-I00 to disrupt any particulate material, and the total amounts of AF in repressed, still and shake culture in this experiment were $10 \%$ or less of the level in de-repressed mycelium.

The easy removal of both enzymes from mycelium indicated either the very fragile nature of some enzyme-containing bodies or that a proportion of the enzymes was located in the hyphal walls, or perhaps a combination of these two possibilities. Mural location of enzymes was examined by treating paraformaldehyde-fixed or unfixed mycelium for $\mathrm{I}$ or 2 min with $0.1 \mathrm{M}$-hydrochloric acid, which was shown by Metzenberg (I963) to inactivate enzymes outside the plasmalemma but not to damage internal enzymes. The results (Table 2) based on assays of both enzymes with several substrates show that some 75 to $85 \%$ of the AF activity and between 30 and $50 \%$ of the AP activity (depending on substrates used) were inactivated by I min of acid treatment, and that doubling the treatment time had little or no extra effect. Mycelium fixed for $16 \mathrm{~h}$ at $4{ }^{\circ} \mathrm{C}$ contained between $\mathrm{I} 3$ and $20 \%$, and 
Table I. Effect of various wash treatments (see text) on the percentage of the total activity of $\alpha$-L-arabinofuranosidase $(A F)$ and acid phosphatase $(A P)$ removed from mycelium. grown 3 days with and without glucose in shake and still cultures

Enzyme removed from mycelium $(\%)$

\begin{tabular}{|c|c|c|c|c|c|c|c|c|}
\hline \multirow[t]{2}{*}{ Culture conditions ... } & \multicolumn{2}{|c|}{ Shaken, + glucose } & \multicolumn{2}{|c|}{ Shaken, no glucose } & \multicolumn{2}{|c|}{ Still, + glucose } & \multicolumn{2}{|c|}{ Still, no glucose } \\
\hline & $\mathrm{AF}$ & AP & $\mathrm{AF}$ & AP & $\mathrm{AF}$ & $\mathrm{AP}$ & $\mathrm{AF}$ & AP \\
\hline $\begin{array}{l}\text { Initial activity }(/ \mathrm{mol}) \\
\mathrm{phenol} / \mathrm{mg} \text { protein } / \mathrm{h})\end{array}$ & $\ldots 0.43$ & $5 \cdot 5$ & $4 \cdot 7$ & $3 \cdot 2$ & 0.33 & $4 \cdot I$ & $3 \cdot 6$ & $4 \cdot 3$ \\
\hline Washed (A) & 8 & 0 & 3 & I & 4 & 3 & 10 & 4 \\
\hline Whirlimixer (B) & 33 & I3 & 58 & 34 & 9 & 6 & 67 & 6 \\
\hline Pipette (C) & 38 & 22 & 58 & 36 & 50 & $2 \mathrm{I}$ & 96 & 18 \\
\hline
\end{tabular}

Table 2. Amount of $\alpha$-L-arabinofuranosidase or acid phosphatase activity (measured with different substrates) remaining in unfixed $(U)$ and fixed $(F)$ mycelium after acid treatment, as a percentage of the activity of unfixed and untreated controls

Mycelium grown for 3 days in shake culture without glucose.

\begin{tabular}{|c|c|c|c|c|c|c|c|c|c|c|}
\hline \multirow{3}{*}{$\begin{array}{l}\text { Substrate ... } \\
\text { Treatments }\end{array}$} & \multicolumn{4}{|c|}{$\alpha$-L-Arabinofuranosidase $(\%)$} & \multicolumn{6}{|c|}{ Acid phosphatase $(\%)$} \\
\hline & \multicolumn{2}{|c|}{$\begin{array}{l}p \text {-Nitro- } \\
\text { phenyl }\end{array}$} & \multicolumn{2}{|c|}{ 2-Naphthyl } & \multicolumn{2}{|c|}{$\begin{array}{l}p \text {-Nitro- } \\
\text { phenyl }\end{array}$} & \multicolumn{2}{|c|}{ 2-Naphthyl } & \multicolumn{2}{|c|}{$\begin{array}{l}\beta \text {-Glycero- } \\
\text { phosphate }\end{array}$} \\
\hline & U & $\mathrm{F}$ & $\mathrm{U}$ & $\mathrm{F}$ & $\mathrm{U}$ & $\mathrm{F}$ & $\mathrm{U}$ & $\mathrm{F}$ & $\mathrm{U}$ & F \\
\hline Control & 100 & 13 & 100 & 20 & 100 & 19 & 100 & 33 & 100 & 15 \\
\hline I $\mathrm{Min} \mathrm{HCl}(\mathrm{O} \cdot \mathrm{I} \mathrm{M})$ & 16 & 10 & 27 & 16 & 65 & 13 & 74 & 32 & 53 & 15 \\
\hline $2 \mathrm{Min} \mathrm{HCl}(\mathrm{O} \cdot \mathrm{I} \mathrm{M})$ & 16 & 10 & 25 & 17 & 65 & 13 & 74 & 32 & 55 & 15 \\
\hline
\end{tabular}

15 and $33 \%$, respectively, of the original AF and AP activities, and these levels were not greatly reduced by either acid treatments. These results therefore indicate the mural location of considerable proportions of both enzymes.

When homogenates of fixed and unfixed mycelium were subjected to disc gel electrophoresis and stained for AF activity, there were indications of a considerable overall loss of activity owing to fixation and a change in the isoenzyme pattern. Incubation of the separate isoenzymes with phosphate-buffered $4 \%$ paraformaldehyde for I h at $4{ }^{\circ} \mathrm{C}$ (Table 3) showed that the main internal isoenzyme (pI 4.5) was the most labile. Similar studies were not carried out for AP, since only one isoenzyme was recovered from mycelial homogenates subjected to isoelectric focusing.

There was also a difference in the percentage reduction of activity of the isoenzymes with pI values of 3 and 6.5 , as assayed with the $p$-nitrophenyl or 2-naphthyl arabinofuranosides. Since AF activity is routinely measured with the former substrate, the specificity of the isoenzymes to both substrates was compared (Table 4 ); when assayed at $\mathrm{pH} 5^{\circ} \mathrm{O}$, the isoenzyme of pI 4.5 hydrolysed the naphthyl substrate four times faster than the nitrophenyl substrate. Both I- and 2-naphthyl $\alpha$-I-arabinofuranosides were hydrolysed at the same rates by the AF isoenzymes, and since the I-naphthyl glycoside was in limited supply this was used for histochemistry while the 2-naphthyl substrate was used for all in vitro studies.

The $\mathrm{pH}$ optimum of AF in whole mycelial homogenates incubated with naphthyl substrates was close to $5^{\circ}$, as were the optima for the isoenzymes with pI values of 3 and 6.5 , but the optimum for the isoenzyme with a pI value of $4 \cdot 5$ was near to $\mathrm{pH} 6 \cdot 5$.

$p$-(Acetoxymercuric) aniline diazotate, at a concentration of $10 \%$ of that used in histo- 
Table 3. Effect of pretreatment (I $h$ at $30{ }^{\circ} \mathrm{C}$ in vitro) of $\alpha$-L-arabinofuranosidase isoenzymes with $4 \%$ paraformaldehyde in $0 \cdot \mathrm{I}$ M-sodium phosphate buffer $\left(\mathrm{pH}_{7} \cdot 3\right)$ on the hydrolysis of nitrophenyl and naphthyl glycosides

$\begin{array}{ccc}\text { Substrate ... } & \overbrace{p \text {-Nitrophenyl }}^{\text {Reduction of activity }(\%)} & \text { 2-Naphthyl } \\ \text { Isoenzyme (pI) } & & \\ 3 \cdot 0 & 18 & 62 \\ 4 \cdot 5 & 100 & 98 \\ 6 \cdot 5 & 10 & 54\end{array}$

Table 4. Specific activity of $\alpha$-L-arabinofuranosidase isoenzymes in the hydrolysis of 2-naphthyl and p-nitrophenyl arabinofuranosides

\begin{tabular}{|c|c|c|c|}
\hline \multirow[b]{2}{*}{ Substrate ... } & \multicolumn{3}{|c|}{ Phenol released $(\mu \mathrm{mol} / \mathrm{mg}$ protein $/ \mathrm{h})$} \\
\hline & $\begin{array}{c}\text { 2-Naphthyl } \\
(A)\end{array}$ & $\begin{array}{c}p \text {-Nitrophenyl } \\
\text { (B) }\end{array}$ & $(A / B)$ \\
\hline \multicolumn{4}{|l|}{ Isoenzyme (pI) } \\
\hline $3 \cdot 0$ & $90 \cdot 0$ & $87 \cdot 7$ & $1 \cdot 02$ \\
\hline $4 \cdot 5$ & $40 \cdot 2$ & $9 \cdot 9$ & $4 \cdot 1$ \\
\hline $6 \cdot 5$ & $102 \cdot 4$ & $109 \cdot 9$ & 0.94 \\
\hline
\end{tabular}

chemical staining of mycelium, caused inhibition in an homogenate of approximately $70 \%$ of $p$-nitrophenyl AF and AP activity and only $40 \%$ of the glycerophosphatase activity. Addition of I-naphthol $(0.5 \mu \mathrm{M})$ did not inhibit the activity of the two enzymes.

Mycelial homogenates prepared by grinding with sand or a glass tissue macerator were layered on a linear sucrose gradient, and after centrifugation approximately $17 \%$ of AF, I0 $\%$ AP, $9 \%$ deoxyribonuclease and $85 \%$ cytochrome $c$ reductase were recovered in particulate fractions as shown in Fig. 2. Some of this 'particulate' material at the top of the gradient (fractions 9 and 10) could be the result of diffusion of soluble material or may indicate the presence of vacuoles of low density, but a small peak of acid hydrolase activity was found in a fraction with a density slightly less than the fraction containing the bulk of the mitochondria (fraction 4 ).

\section{Histochemical}

Mycelium growth was more profuse and the hyphae thicker in the glucose-supplemented media than in the absence of glucose, but phase- and interference-contrast microscopy revealed no other consistent structural differences. Hyphal tips showed no distinctive features and had a general appearance similar to that described by Maxwell, Williams \& Maxwell (I970). Woronin bodies were conspicuous at many septa and the vacuolation was variable, while the contents of mycelium grown in shake culture showed more pronounced Brownian movement than those of mycelium from still cultures. Mycelium stained with Nile Blue (e.g. Armentrout, Smith \& Wilson, 1968) fluoresced at numerous small particulate sites.

Fixed and unfixed mycelium from liquid or agar cultures stained for AF or AP activity by simultaneous coupling and post-coupling azo-dye techniques always indicated a particulate (diameter 0.1 to $0.8 \mu \mathrm{m}$ ) localization of both enzymes against a lightly stained diffuse background (Fig. $3 a$ ). Nuclear or wall staining was never obvious, and there were no conspicuous differences in the staining patterns of the enzymes although AF 'particles' always developed before AP ' particles'. Stained sites were apparently randomly distributed throughout 2- to 4-day-old mycelium and although 'particles' were commonly seen at hyphal tips 


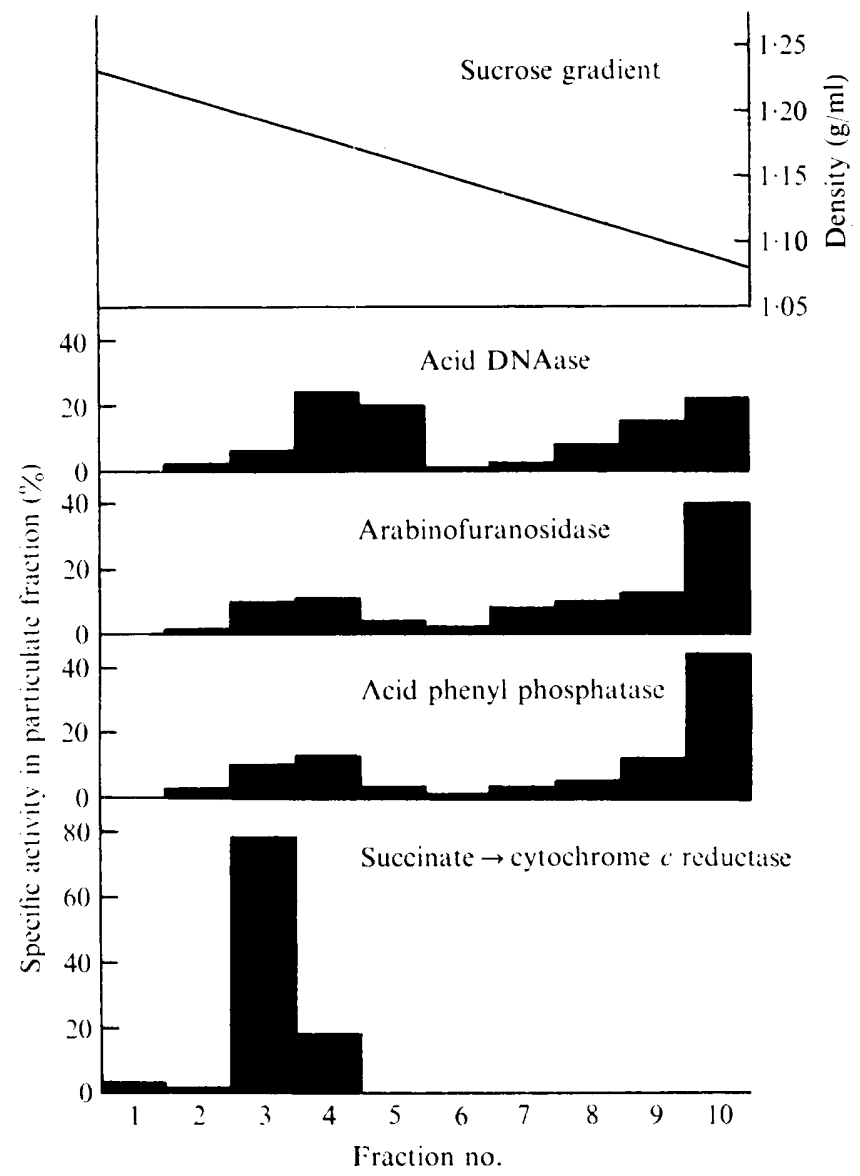

Fig. 2. Percentages of the sedimentable activities of enzymes recovered from fractions of a sucrose density gradient following centrifugation.

they were not concentrated in this region. Prolonged staining caused an enlargement of the stained sites and increased diffuse staining, but in the time required to stain de-repressed mycelium (30 to $60 \mathrm{~min}$ ) negligible staining developed in the glucose-supplemented cultures. If the microscope was focused through the mycelium, some stained sites were seen to be close to the hyphal walls resulting in a pimply appearance.

Latency of the staining reaction was examined for both enzymes (Table 5) and although the activation caused by some treatments was less spectacular than that obtained with AP in higher plant cells (Gahan, 1965) and in fungal hyphae (Pitt, I968; Wilson, Stiers \& Smith, 1970), the results indicate possible structure-linked latency. The effect of Triton X-I00 on staining was dependent on the duration of pre-incubation with the surface active agent, since treatment for $\mathrm{I} h$ caused some sites, particularly at hyphal tips, to stain very rapidly ( $<5 \mathrm{~min}$ ) although $2 \mathrm{~h}$ treatment almost abolished the usual small stained sites. Preincubation of mycelium in $1 \mathrm{O}^{-2} \mathrm{M}$-sodium fluoride for $\mathrm{I} h$ usually inhibited AP staining but had no effect on AF staining, which was also unaffected by pretreatment and incubation with $5 \times 10^{-2} \mathrm{M}-\gamma$-arabonolactone. Although fixed mycelium stained less quickly than unfixed mycelium (approx. $40 \mathrm{~min}$ and $30 \mathrm{~min}$ respectively), the end result was not conspicuously different for either enzyme. In all the staining experiments carried out, a 

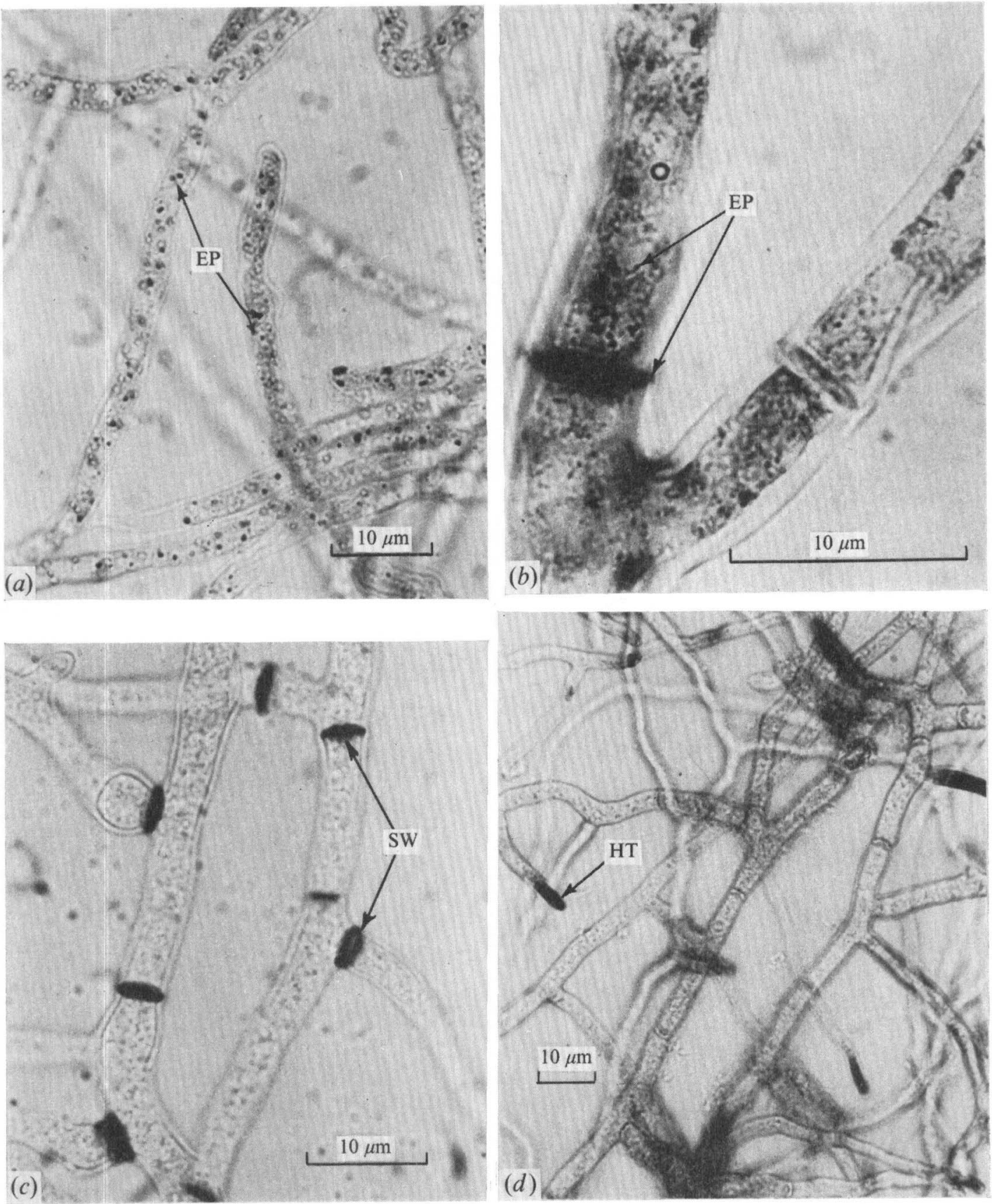

Fig. 3. (a) AF localized in fixed mycelium. $(b, c, d)$ AP localized by the Gomori technique. $(b)$ Standard Gomori mixture, fixed mycelium; local cytoplasmic staining and septal wall staining. (c) Septal walls only stained in low substrate mixture (I mM glycerophosphate). (d) Hyphal tips selectively stained in fixed mycelium.

Abbreviations used in Figs. 3 to 8: EP, enzyme product; HT, hyphal tip; M, mitochondria; MVB, multivesicular body; N, nucleus; Pl, plasmalemma; S, spherosome; SLB, spherosome-like body; SW, septaı wall; V, vacuole; W, hyphal wall. 


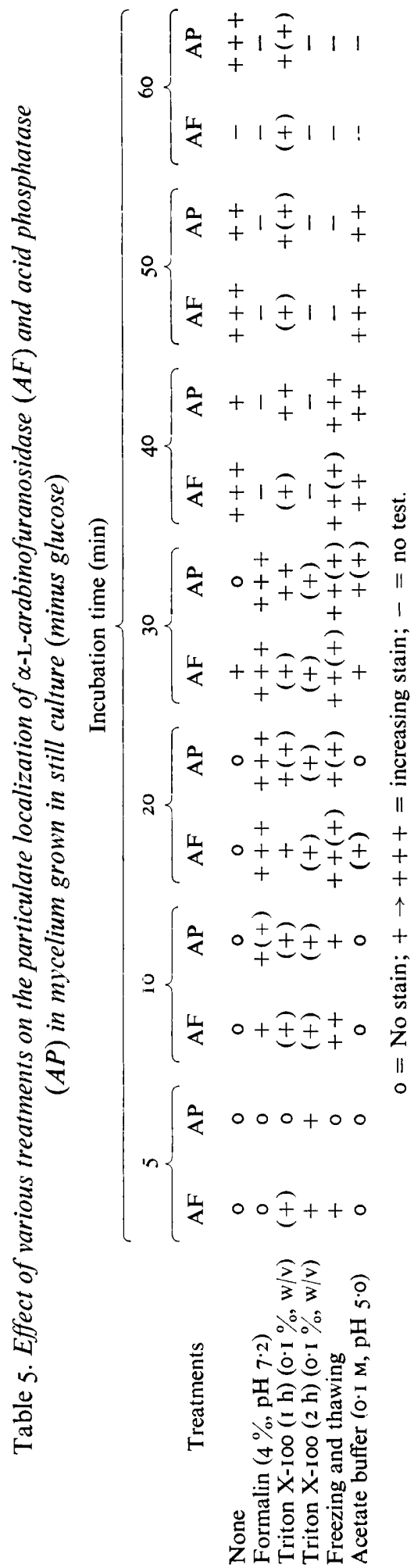



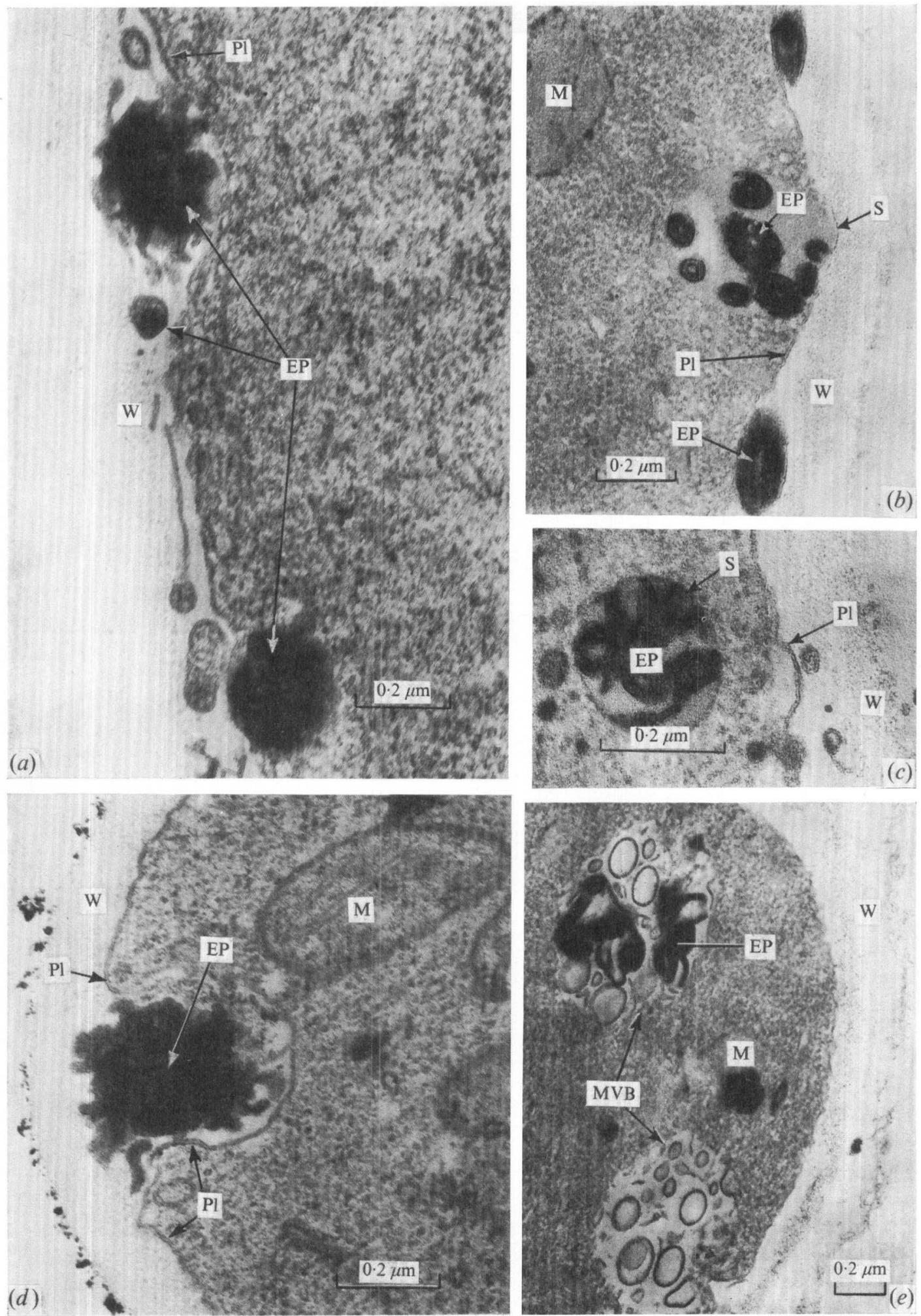

Fig. 4. AF localization in de-repressed mycelium. For abbreviations, see f.n. to Fig. 3. 

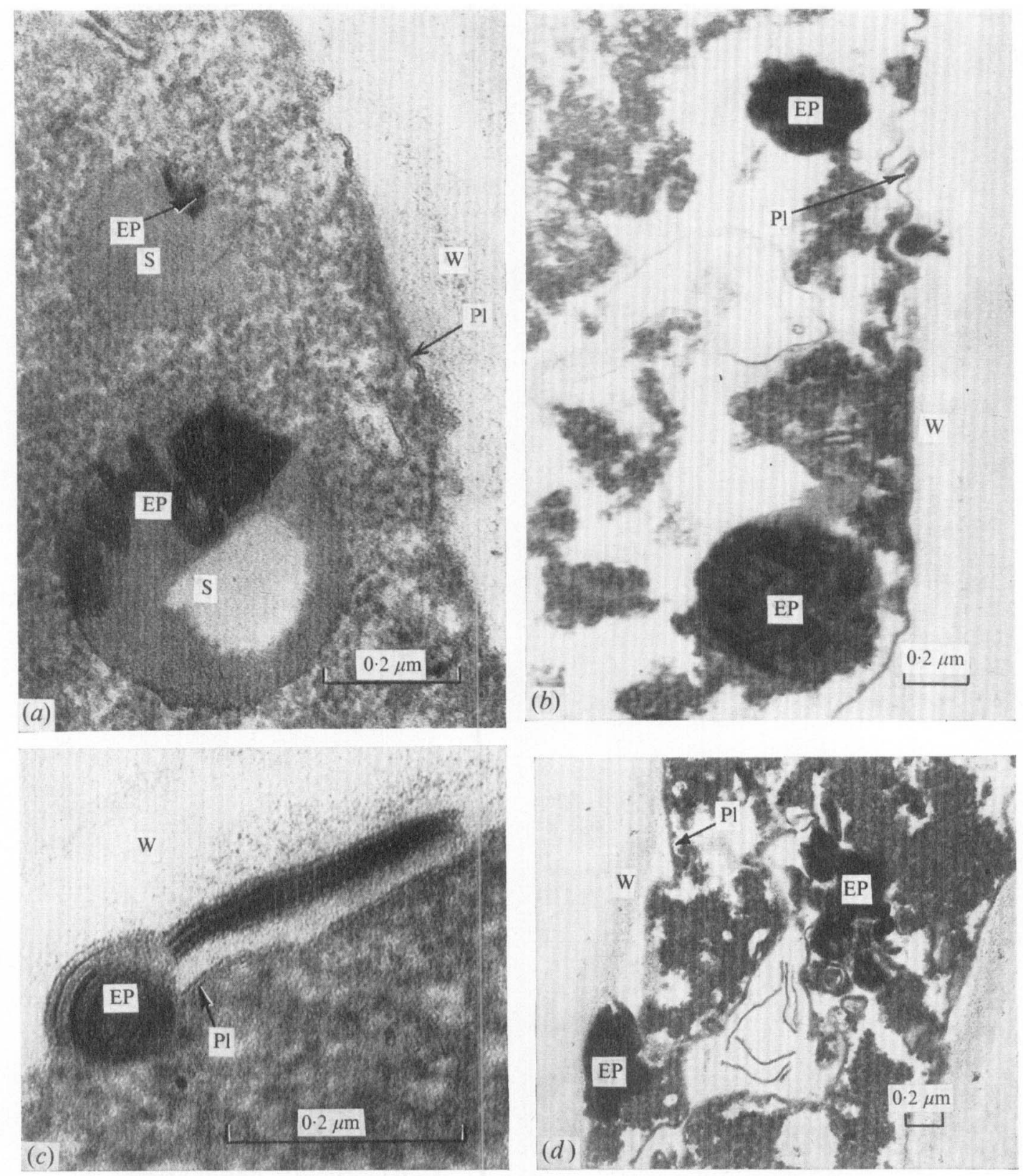

Fig. 5. ( $a, c)$ AF localization in de-repressed fixed mycelium. $(b, d)$ AF localization in unfixed mycelium. For abbreviations, see f.n. to Fig. 3.

proportion of the hyphae failed to show particulate staining as reported for Achlya mycelium by Palczewska \& Jagodzka (I972). Mycelium fixed for I h in $4 \%(w / v)$ gluteraldehyde at room temperature stained less uniformly and less quickly for AF than that fixed in paraformaldehyde. Since Smith \& Fishman (1969) found that the dialdehyde caused control tissues to develop a stronger avidity for $p$-(acetoxymercuric) aniline diazotate, this fixative was not used further in the present work. 

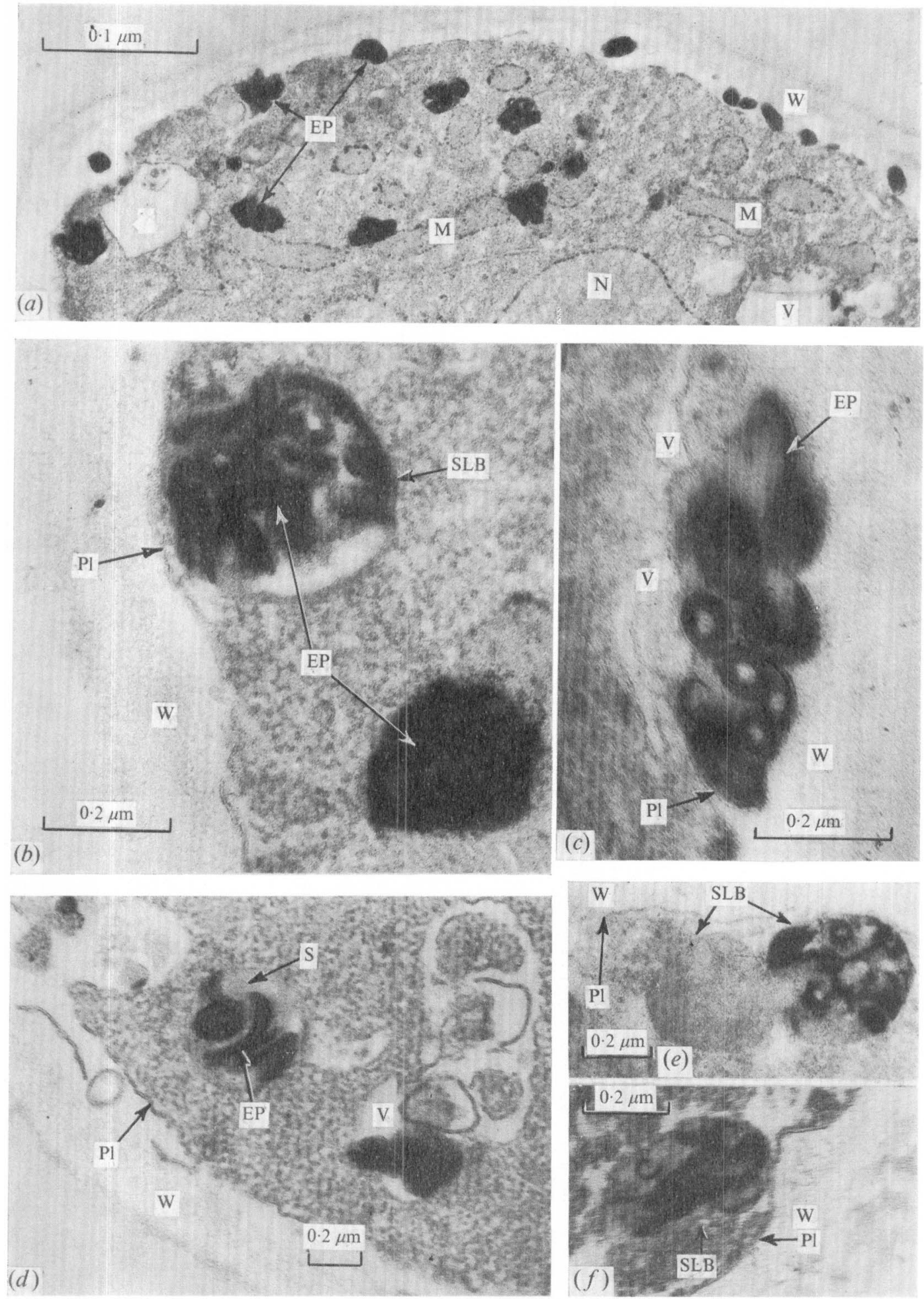

Fig. 6. AP localization in de-repressed fixed mycelium [except in $(f)$ it is unfixed] by the azo-dye methods. For abbreviations, see f.n. to Fig. 3 . 

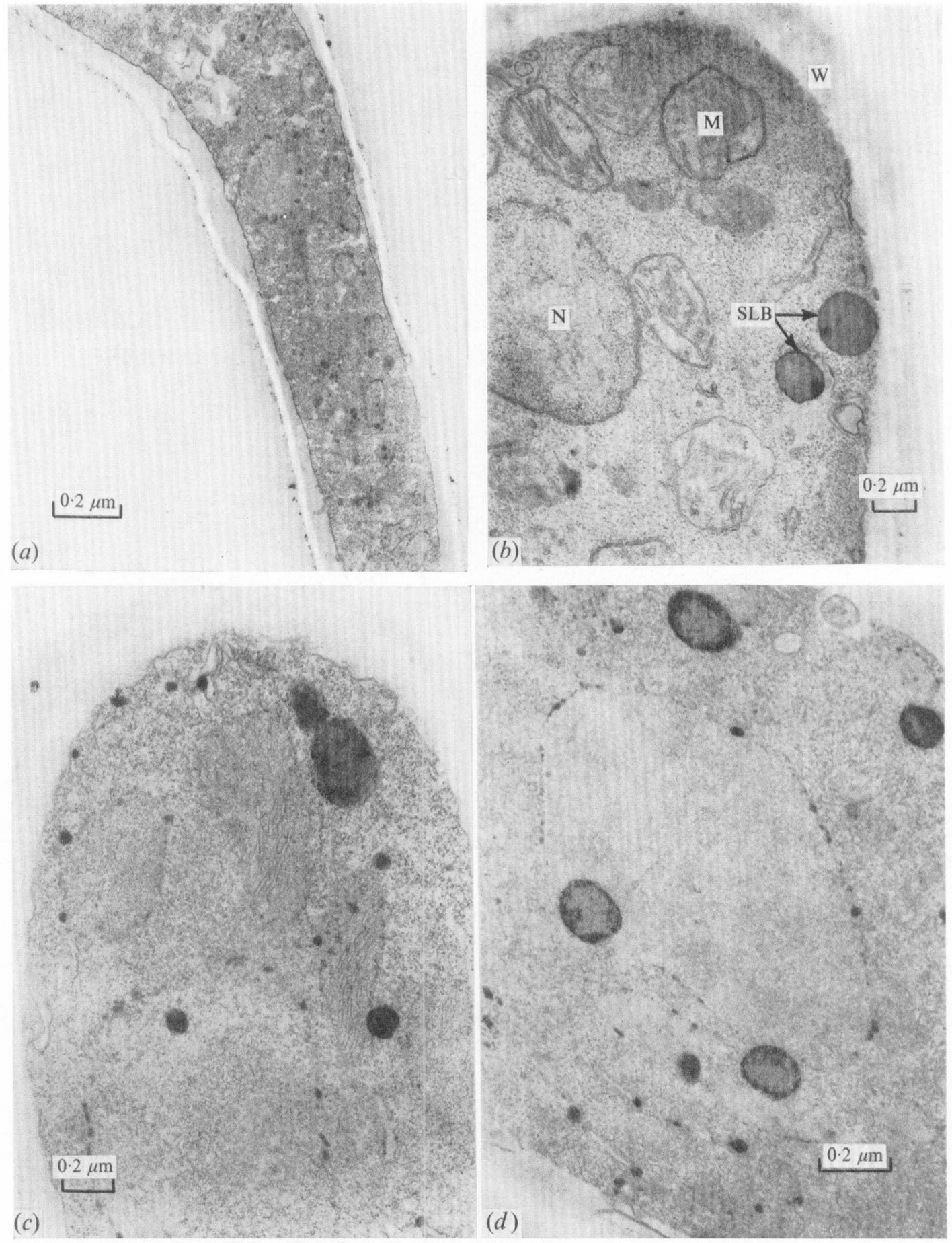

Fig. 7. Fixed mycelium controls. (a) AF staining of repressed mycelium. (b) AP staining in the presence of $10^{-2} \mathrm{M}-\mathrm{NaF}$. (c) Mycelium preincubated with I-naphthol. (d) 'No substrate' control. For abbreviations, see f.n. to Fig. 3. 

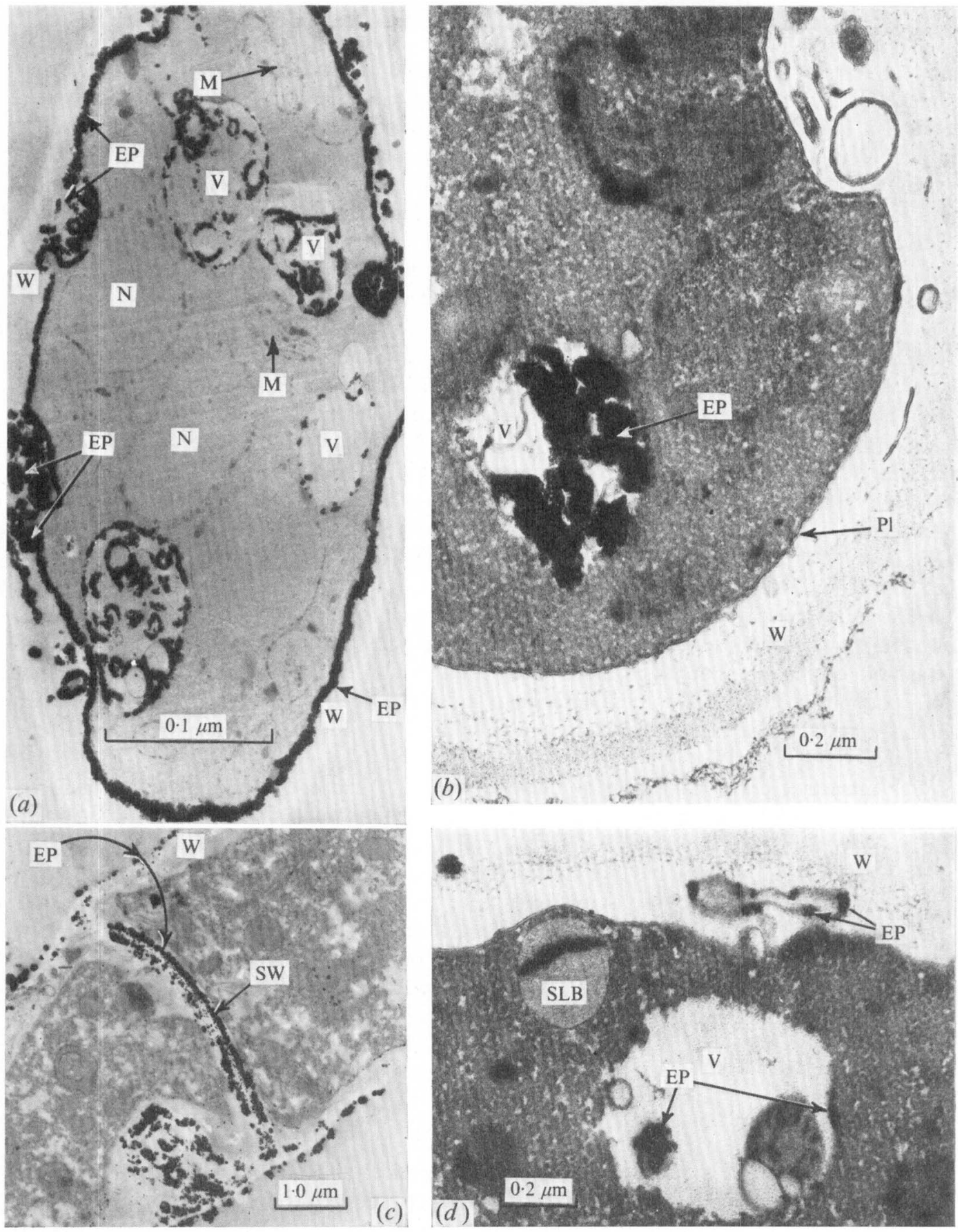

Fig. 8. AP by the Gomori method. (a) De-repressed mycelium not post-stained. (b) As (a), but poststained. $(c, d)$ Repressed mycelium. For abbreviations, see f.n. to Fig. 3. 
By comparison with results obtained with the azo-dye techniques, AP localization by the Gomori (1952) method was very variable. The mycelium stained either poorly or very heavily, and nuclear staining was often seen. Normal particulate staining was often confined to certain cells in a hypha, and occasionally a septum stained strongly (Fig. $3 b$ ). When a lower substrate concentration (I mM) was used, septal staining was highly conspicuous in some hyphae (Fig. $3 c$ ), although no particulate staining developed. This substrate concentration sometimes caused conspicuous diffuse staining of fixed hyphal tips (Fig. $3 d$ ). The reasons for this variability in AP localization were not examined in the present study.

Examination of thin sections of fixed, stained (acetoxymercuric aniline diazotate) mycelium (Fig. 4 to 6) revealed a similar pattern of ultrastructural localization for both enzymes. Low-power magnifications often revealed many sites stained for AF or AP in de-repressed mycelium and also for AP in repressed mycelium, and some of the sites were clearly between the plasmalemma and the hyphal walls (e.g. AF, Fig. $4 a, b$; AP, Fig. $6 a, c$ ). AF activity was also seen in 'simple' vacuoles or vacuoles containing small vesicles (e.g. Fig. $4 e$ ). AP was also seen in similar vacuoles (e.g. Fig. $6 b, d$ ). Alternatively, both enzymes occurred at sites stained so densely that no structure was evident (Fig. $6 b$ ) or in less dense bodies where the enzymes showed characteristic patterns of staining (e.g. AF in Fig. $4 b, c, 5 a$; AP in Fig. $6 d, e$ ). Control mycelium (Fig. 7) showed no stained sites similar to those seen in Fig. 4 to 6 , although some non-specific deposition of dye occurred on nuclear and mitochondrial surfaces and in 'lipid bodies'.

The ultrastructure of mycelium which had undergone the full histochemical treatment was fairly well preserved, but although sections were frequently difficult to post-stain, this was not considered a serious problem since details of stained sites were best seen in material of low contrast. Golgi bodies were not seen in any of the sections, and endoplasmic reticulum was sparse. Lomosomes and multi-vesicular bodies were rather rare in most material examined.

AP ultrastructural localization by the Gomori (1952) method showed some similarities to that revealed by the azo-dye technique in that activity was often evident in vacuoles (Fig. $8 a, b, d$ ) and at the plasmalemma (Fig. $8 a, b$ ), although the small dense bodies (Fig. $8 a$ ) were rare and spherosome-like bodies which showed the striking azo-stain distribution were not seen. The photographs in Fig. 8 were all taken from mycelium stained on one occasion and illustrate the variability of the reaction. In some sections lead was uniformly deposited on the plasmalemma or on either side of a septal wall (Fig. 8c) in a manner never seen for the deposition of azo dye. In other sections lead was sometimes localized at discrete sites on or outside the plasmalemma and in nuclei (not shown). Mycelium incubated in mixtures containing sodium fluoride was almost devoid of lead deposits.

\section{DISCUSSION}

The present report attempts to correlate biochemical and cell fractionation data with ultrastructural histochemical observations on mycelium, an approach which overcomes some of the problems of interpreting information obtained from cell-free fractions, or from histochemical techniques alone. For historical reasons, and because of the ease with which it can be demonstrated biochemically, histochemically and cytochemically, acid phosphatase has become the principal marker enzyme for lysosomes, and although AF was the main object of our study the apparent similarity between the localization of this enzyme and AP clearly indicated a consideration of the lysosome concept as it might apply to our results. 
Lysosomes are difficult to define because of their great pleomorphism and variable function, but in the broadest sense they are membrane-bounded bodies containing digestive enzymes involved in controlled cellular lytic processes (not to be confused with autolysis). Spherosomes, recognized as distinct organelles of fungi (e.g. Wilson et al. 1970), are a type of primary lysosome, while larger vacuoles can be regarded as secondary lysosomes (Matile, 1969). At the light-microscope level the appearances of unfixed, fixed or acid-treated mycelium stained for AF or AP in our study were not conspicuously different, indicating the limitations of such observations (Gahan \& McLean, 1969), but the ultrastructural localization of both enzymes in a variety of organelles (e.g. vacuoles, see Fig. $4 e$; and in spherosomelike bodies, see Fig. $4 b, e$ ) indicates that AF could now be considered a lysosomal enzyme. However, our results, like those of Maxwell et al. (1972) and Halperin (1969), do not clearly implicate multivesicular bodies (Calonge et al. 1969) in the secretion of AF or AP.

The fact that we were unable to sediment appreciable quantities of either enzyme does not necessarily contradict the lysosomal hypothesis, since those proportions of the enzymes which occur between the plasmalemma and the hyphal walls, in vacuoles, and in other structures might be expected to be solubilized by the fairly vigorous grinding necessary to disrupt the mucus-coated mycelium. Plant tissues and fungi, unlike the majority of animal tissues, have rarely yielded large porportions of the lysosomal enzymes in sediments, but this may be a matter of technique since recently Cartledge \& Lloyd (I972 $a, b)$ and Pitt \& Galpin (1973) have sedimented acid hydrolases from yeast cells and from dark-grown potato shoots respectively. Pitt \& Galpin attributed their success to the use of Ficoll rather than sucrose gradients, while Cartledge \& Lloyd produced their homogenates by the disruption of sphaeroplasts. Our attempts to use both of these techniques in the present study were unsuccessful, although we found that vacuoles obtained from broken protoplasts by flotation (Matile \& Wiemken, 1967) did contain some AF activity (unpublished data).

Cartledge \& Lloyd (1972 b) and Pitt \& Galpin (1973), amongst others, found that the activity of acid phosphatase in a subcellular fraction could depend greatly on the substrate used to measure it, e.g. glycerophosphatase as distinct from phenylphosphatase. This may explain our failure to stain spherosome-like bodies by the lead technique. The pictures of spherosomes in Ceratocystis mycelium stained for AP by Wilson et al. (1970) are difficult to interpret and do not negate this hypothesis.

Our observations on glycerophosphatase in septal walls are also difficult to interpret, since although its mural location in higher plant cells is well known (e.g. Hall \& Butt, I968; Halperin, I969), this location has not been reported previously for fungal mycelium. Further, Hayashi (197I), using an azo dye and lead ions to capture the products of AP action on I-acetyl-3-indoxyl phosphate, found that while latency could be demonstrated by the lead method the azo-dye technique produced negative results. Gahan (I965), Pitt (I968) and Wilson et al. (I970) all used the lead method in their latency tests of plant and fungal 'lysosomes', and our less spectacular (although positive) results in demonstrating the latency of AF and AP in Sclerotinia fructigena could have been due to our choice of technique. Although substituted naphthyl phosphates, which on hydrolysis produce naphthols of low solubility suitable for post-coupling, are available commercially, we chose to use I-naphthyl phosphate to compare directly with I-naphthyl $\alpha$-L-arabinofuranoside which (with the 2-naphthyl glycoside) was the only histochemical substrate available for the demonstration of AF. The choice of these substrates necessitated the adoption of a simultaneous coupling technique, even though the diazonium salt finally chosen as a coupling agent was somewhat inhibitory to the activity of both enzymes under study. 
Hexazotized pararosaniline was not an effective coupling agent, probably because the end-product was removed during embedding (Livingston et al. 1969).

As fixation caused a considerable reduction in the activity of the enzymes, the staining seen in the electron microscope probably represented at best only $20 \%$ of their original activity. Although phenylphosphatase of Sclerotinia fructigena appears to exist in one form (unpublished data from isoelectric focusing of mycelial homogenates), AF exists in at least three forms, one of which is particularly sensitive to formalin. If, as is possible (see Straus, 1967), these isoenzymes are localized in different organelles, then the results obtained so far are incomplete and a true localization must await more effective sedimentation techniques and the use of more specific cyto- or immuno-chemical methods.

As reported by Smith \& Fishman (1969), the spherosome-like bodies (Fig. $4 b, c ; 5 a$; $6 d, e)$ which stained so characteristically for AP and AF took up some stain in control material, although the pattern and density of staining was quite different. Thiocarbohydrazide increased the deposition of osmium. on lipid bodies as well as in oil drops, and this could account for the diffuse staining seen in such bodies in some control sections. However, this would not be expected to cause the deposition of stain in the striking patterns so often seen in other enzyme-positive sections and does not explain why some bodies in the same sections (e.g. Fig. 6e) show little or no stain.

Careful examination of the unstained spherosome in Fig. 6(e) shows that this body has some internal structure in the form of 'whorls', and it is suggested that these might be the sites at which active enzyme is bound in the adjacent stained body. Unfortunately, such bodies are difficult to find in sections and are only clearly seen after the deposition of a small but apparently critical amount of post-stain (uranyl acetate and/or lead citrate). Buckley, Sommer \& Matsumoto (1968) also observed structural detail in 'spherosome-like' bodies of Rhizopus spp. and suggested that this could be due to the presence of proteins, possibly of an enzymic nature. Liposomes (Williams \& Webster, 1970) are probably also the equivalent of spherosomes, and cleavage of the cytoplasm of sporangiophores of Phytophthora capsici was accompanied by a change in density of the liposomes and the development in them of striations. The products of enzyme action seen in the form of 'striations' and 'whorl (Fig.s' $4 b, 5 c$ ) between the plasmalemma and the hyphal wall in the present study may result from the disruption of secreted spherosomes so that this enzyme is then available to the outside medium (e.g. Fig. $5 a \rightarrow 4 b \rightarrow 4 d \rightarrow 4 a \rightarrow 6 c$ ).

Some 'compound' vacuoles containing enzyme-positive vesicles were also open to the extracellular medium and these could contribute to extracellular activity. We have not been able to observe the origin of the enzyme-containing vesicles, but they might have arisen by the fusion of spherosomes with vacuoles or the conversion of spherosome-like bodies into vacuoles (e.g. Fig. $5 a, 6 b$ ).

The ultrastructural detail in mycelium stained for enzyme activity before fixation was poor, but reaction product was seen in spherosome-like bodies (Fig. $5 b, 6 f$ ) and in what may have been a 'compound' vacuole (Fig. $5 d$ ).

The small amount of data available at present on the removal of AF from mycelium (Table I) indicates that enzymes outside the plasmalemma is not bound to the wall, so that the final process of secretion may be one of diffusion. Brown (1917) in classical studies with Botrytis cinerea suggested that pectolytic enzymes of this fungus were only secreted at the hyphal tips and some (circumstantial) evidence in favour of this has been given by Hall (1971). AF activity from Sclerotinia fructigena growing in agar has been demonstrated ahead of the hyphal tips, but whether or not it originates only at the tip is not clear. Observations of living hyphae by Armentrout et al. (1968) and Maxwell et al. (1970) indicated that 
spherosomes were especially concentrated at hyphal tips, but like Palczewska \& Jagodzka (1972) we found that while enzymes could be localized in hyphal tips by histochemical means, they were not particularly concentrated there.

We have studied the production and secretion of AF by Sclerotinia fructigena grown in artificial culture as a prelude to further work on its importance in pathogenesis in vivo. Preliminary histochemical examination of mycelium growing in apple fruit tissue by the technique used in vitro failed to demonstrate the presence of AF even though AP was well visualized. Wergin (1972) has shown that Fusarium oxysporum grown in vivo compared with in vitro contained visibly different microbodies, and clearly therefore the localization of $\mathrm{AF}$ in pathogenic mycelium is of considerable interest.

F. Laborda thanks the Spanish Ministerio de Educacion y Ciencia for financial support. We greatly appreciate the assistance of $\mathrm{Mr} \mathrm{A}$. H. Fielding with many aspects of this work.

\section{REFERENCES}

Altman, F. P. (1971). The use of a new grade of polyvinyl alcohol for stabilizing tissue sections during histochemical incubations. Histochemie 28, 236-242.

ArCher, S. A. (1973). Physiological aspects of brown rot of apple. Ph.D. Thesis, University of Bristol.

Armentrout, V. M., Smith, G. G. \& Wilson, C. L. (I968). Spherosomes and mitochondria in the living fungal cell. American Journal of Botany 55, 1062-1067.

Berthet, J. \& DE Duve, C. (I95I). Tissue fractionation studies. I. The existence of a mitochondrial-linked, enzymically inactive form of acid phosphatase in rat-liver tissue. Biochemical Journal 50, I74-I8I.

Bradshaw, W. S. \& RutTer, W. J. (1972). Multiple pancreatic lipases. Tissue distribution and pattern of accumulation during embryological development. Biochemistry II, I517-1528.

Brown, W. (I917). Studies in the physiology of parasitism. IV. On the distribution of cytase in cultures of Botrytis cinerea. Annals of Botany 3r, 489-498.

Buckley, P. M., Sommer, N. F. \& MAtsumoto, T. T. (1968). Ultrastructural details in germinating sporangiospores of Rhizopus stolonifer and Rhizopus arrhizus. Journal of Bacteriology 95, 2365-2373.

Burstone, M.S. (1962). Enzyme Histochemistry and its Application in the Study of Neoplasms, $621 \mathrm{pp.}$ New York: Academic Press.

Byrde, R. J. W. \& Fielding, A. H. (1965). An extracellular $\alpha$-L-arabinofuranosidase secreted by Sclerotinia fructigena. Nature, London 205, 390-391.

Byrde, R. J. W. \& Fielding, A. H. (1968). Pectin methyl-trans-eliminase as the maceration factor of Sclerotinia fructigena and its significance in brown rot of apple. Journal of General Microbiology $\mathbf{5 2}^{2}$, 287-297.

Calonge, F. D., Fielding, A. H. \& Byrde, R. J. W. (1969). Multivesicular bodies in Sclerotinia fructigena and their possible relation to extracellular enzyme secretion. Journal of General Microbiology 55, 177I84.

Cartledge, T. G. \& Lloyd, D. (1972a). Subcellular fractionation by differential and zonal centrifugation of aerobically-grown glucose-derepressed Saccharomyces carlsbergensis. Biochemical Journal 126, $38 \mathrm{I}-393$.

Cartledge, T. G. \& Lloyd, D. (1972 b). Subcellular fractionation of particles containing acid hydrolases from Saccharomyces carlsbergensis. Biochemical Journal x26, 755-757.

Davis, B. J. \& Ornstein, L. (1959). High resolution enzyme localization with a new diazo reagent 'hexazonium pararosaniline'. Journal of Histochemistry and Cytochemistry 7, 297-298.

FIELDING, A. H. \& BYRDE, R. J. W. (I969). The partial purification and properties of endopolygalacturonase and $\alpha$-L-arabinofuranosidase secreted by Sclerotinia fructigena. Journal of General Microbiologv $\mathbf{5 8}^{\mathbf{8}}$ $73-84$.

FIELding, A. H. \& Hough, L. (I965). The synthesis of $p$-nitrophenyl $\alpha$-L-arabinofuranoside. Carbohydrate Research I, 327-329.

Fielding, A. H. \& Hough, L. (197I). The synthesis of 2-naphthyl $\alpha$-L-arabinofuranoside. Carbohydrate Research 20, 416-417.

Fiske, C. H. \& Subba Row, Y. (1925). The colorimetric determination of phosphorus. Journal of Biological Chemistry 66, 375-400. 
GaHAN, P. B. (1965). Histochemical evidence for the presence of lysosome-like particles in root meristem cells of Vicia faba. Journal of Experimental Botany 16, 350-355.

Gahan, P. B. \& MCLean, J. (1969). Subcellular localization and possible functions of acid $\beta$-glycerophosphatase and naphthyl esterases in plant cells. Planta 89, I26-135.

Gomori, G. (1952). Acid phosphatase. In Microscopic Histochemistry, 193 pp. Chicago University Press.

Grogg, E. \& Pearse, A. G. E. (I952). A critical study of the histochemical techniques for acid phosphatase and a description of the azo dye method. Journal of Pathology and Bacteriology 64, 627-636.

Hall, J. L. \& BuTt, V. S. (1968). Localization and kinetic properties of $\beta$-glycerophosphatase in barley roots. Journal of Experimental Botany 19, 276-287.

Hall, R. (1971). Pathogenicity of Monilinia fructicola. I. Hydrolytic enzymes. Phytopathologische Zeitschrift 72, 245-254.

HALPERIN, W. (I969). Ultrastructural localization of acid phosphatase in cultured cells of Daucus carota. Planta 88, 9I-102.

HayashI, M. (197I). Demonstration of acid phosphatase activity using I-acetyl-3-indoxyl phosphate as substrate. Journal of Histochemistry and Cytochemistry 19, 175-18 1 .

Hislop, E. C. \& Stahmann, M. A. (I97I). Peroxidase and ethylene production by barley leaves infected with Erysiphe graminis f.sp. hordei. Physiological Plant Pathology r, 297-312.

Howell, H. E. (1972). Production of extracellular enzymes by Sclerotinia fructigena Aderh. \& Ruhl: some observations on their importance in pathogenesis and on their inheritance. Ph.D. Thesis, University of Bristol.

KunItz, M. (1950). Crystalline deoxyribonuclease. I. Isolation and general properties. Spectrometric method for the measurement of deoxyribonuclease activity. Journal of General Physiology 33, 349-362.

LABorda, F., Fielding, A. H. \& BYrde, R. J. W. (I973). Intra- and extra-cellular $\alpha$-L-arabinofuranosidase of Sclerotinia fructigena. Journal of General Microbiology 79, 32 I-329.

LehreR, G. M. \& ORNSTEIN, L. (1959). A diazo coupling method for the electron microscopic localization of cholinesterase. Journal of Biophysical and Biochemical Cytology 6, 399-404.

Livingston, D. C., Coombs, M. M., Franks, L. M., Maggi, V. \& Gahan, P. B. (ig69). A lead phthalocyanin method for the demonstration of acid hydrolases in plant and animal tissues. Histochemie 18, $48-60$.

Lowry, O. H., Rosebrough, N. J., Farr, A. L. \& Randall, R. J. (I95I). Protein measurement with the Folin phenol reagent. Journal of Biological Chemistry 193, 265-275.

LUFT, J. H. (1961). Inprovements in epoxy resin embedding methods. Journal of Biophysical and Biochemical Cytology 9, 409-4I4.

Matile, P. \& WiemKen, A. (1967). The vacuole as the lysosome of the yeast cell. Archiv für Mikrobiologie 56, I48-I 55.

Matile, P. (1969). Plant lysosomes. In Lysosomes in Biology and Pathology, pp. 406-430. Edited by J. T. Dingle and H. B. Fell. Amsterdam and London: North Holland Publishing.

Maxwell, D. P., Williams, P. H. \& Maxwell, M. D. (1970). Microbodies and lipid bodies in the hyphal tips of Sclerotinia sclerotiorum. Canadian Journal of Botany 48, I689-I69I.

Maxwell, D. P., Williams, P. H. \& Maxwell, M. D. (1972). Studies on the possible relationships of microbodies and multivesicular bodies and oxalate, endopolygalacturonase and cellulase (Cx) production by Sclerotinia sclerotiorum. Canadian Journal of Botany 50, 1743-1748.

METZENBERG, R. L. (1963). The localization of $\beta$-fructofuranosidase in Neurospora. Biochimica et biophysica acta $77,455-465$.

PalCZEWSKA, I. \& JAGODZKA, G. (1972). Cytochemical localization of certain hydrolytic enzymes at various stages of development of Achlya flagellata mycelium. Acta Societatis botanicorum Poloniae 4r, 265-282.

PITT, D. (I968). Histochemical demonstration of certain hydrolytic enzymes within cytoplasmic particles of Botrytis cinerea Fr. Journal of General Microbiology 52, 67-75.

PITT, D. \& GALPIN, M. (1973). Isolation and properties of lysosomes from dark-grown potato shoots. Planta 109, 233-258.

REYNOLDS, E. S. (1963). The use of lead citrate at high $\mathrm{pH}$ as an electron-opaque stain in electron microscopy. Journal of Cell Biology 17, 208-21 3 .

SMith, R. E. \& Fishman, W. H. (1969). p-(Acetoxymercuric) aniline diazotate, a reagent for visualizing the naphthol AS BI product of acid hydrolase action at the level of the light and electron microscope. Journal of Histochemistry and Cytochemistry 17, I-22.

SPURR, A. R. (1969). A low viscosity epoxy resin embedding medium for electron microscopy. Journal of Ultrastructure Research 26, 31-43. 
Straus, W. (1967). Lysosomes, phagosomes and related particles. In Enzyme Cytology, pp. 239-319. Edited by D. B. Roodyn. London and New York: Academic Press.

Ulrich, J. T. \& MATHRE, D. E. (1972). Mode of action of oxathiin systemic fungicides. V. Effect on electron transport system of Ustilago maydis and Saccharomyces cerevisiae. Journal of Bacteriology 110, 628-632.

WERGIN, W. P. (1972). Ultrastructural comparison of microbodies in pathogenic and saprophytic hyphae of Fusarium oxysporum f.sp. lycopersici. Phytopathology 62, 1045-1051.

Williams, W. T. \& Webster, R. K. (1970). Electron microscopy of the sporangium of Phytophthora capsici. Canadian Journal of Botany 48, $22 \mathrm{I}-227$.

Wilson, C. I., Stiers, D. L. \& Smith, G. G. (1970). Fungal lysosomes or spherosomes. Phytopathology 60 , 216-227. 